\title{
Relationship Between Working Capital Management and Profitability in Turkey Industrial Listed Companies
}

\author{
Necdet Saglam \\ Anadolu University, Eskisehir, Turkey
}

\author{
Aziz Kagitci, Semih Buyukipekci \\ Selcuk University, Selcuk, Turkey
}

\begin{abstract}
The present study investigated the effect of working capital management component on corporate profitability. A sample of 106 firms listed on Borsa Istanbul Stock Exchange (BIST) for the period of 2003-2013 was used. The secondary data for analysis were taken from Bloomberg's Database. The present study aims to explore the effect of working capital management components on corporate profitability. We observed that there was a negative correlation between gross operating profit and accounts receivables (A/R). We also found that there was a positive correlation between gross operating profit and number of days inventory. But they did not affect the profitability of firms in the study at a significant level.
\end{abstract}

Keywords: working capital management, profitability, cash conversion cycle

\section{Introduction}

Making decisions on working capital management takes most of the time of a finance manager. Fixed capital and financing of these may be formed by much greater amounts. However, fixed capital is not very common among businesses. On the other hand, many procedures such as raw materials purchase, worker wage payments, sale of goods, and collection of accounts receivables (A/R) are related to working capital management. At which level to keep that many working capital components and how to finance these are among the most important decisions to be made by finance managers.

Most important of the working capital components are cash and cash equivalents, trade receivables, inventories, trade payables, and bank loans. Managers meet many limitations while deciding at which levels to keep these components. If the cash and cash equivalents of enterprises are at an inadequate level, the risk of default increases. Such enterprises may not meet their liabilities on time. Companies that keep a redundant amount of cash equivalents have to give up on the profits to be obtained from their present activities. An enterprise that wants to increase the sales may want to extend the maturity date for their customers. What is important at this point is how to meet the financial need that will occur at this situation. In such a situation, enterprises may ask their suppliers to extend their maturity date or use bank loans. Keeping extra stocks in order to meet any demand growth means giving up on the interest yield of the capital tied up on the stocks.

Do the decisions made by the managers in the above-mentioned situations affect the profitability of a company? There are many studies conducted to answer this question. Shin and Soenen (1998), Deloof (2003), Lazaridis and Tryfonidis (2006), Ganesan (2007), Raheman and Nasr (2007), Nazir and Afza (2009), Mathuva

Necdet Saglam, professor of Accounting and Finance, Anadolu University. Email: nsaglam@anadolu.edu.tr.

Aziz Kagitci, lecturer, Vocational School of Social Sciences, Selcuk University.

Semih Buyukipekci, assistant professor, Faculty of Tourism, Selcuk University. 
(2010), Gill, Biger, and Mathur (2010), Mohamad and Saad (2010), Ching, Novazzi, and Gerab (2011) and many other researchers have studied the effect of working capital management on profitability. Like many other previous researches in the literature, the purpose of the present research is to examine the correlations between working capital management and profitability. Data of the present research were obtained from 106 publicly-traded companies in BIST Industrials.

\section{Literature Review}

Shin and Soenen (1998) studied the correlations between the efficiency of working capital management and company profitability in their research conducted on 58,985 company/year data of 1975-1994 periods. They studied the correlation between net trade cycle and profitability. Net trade cycle is calculated in a similar way with cash conversion cycle. Unlike cash conversion cycle, all components are divided into sales for the calculation of net trade cycle. Independent variables of the research were: current ratio, debt ratio, and sales growth. They found a strong negative correlation between net trade cycle and company profitability. Shin and Soenen (1998) reported that increases in current ratio and debt ratio reduced company profitability.

Deloof (2003) studied that effect of working capital management on profitability with the 1992-1996 period data obtained from 1,009 large-scale Belgian companies. According to the findings, there is a strong negative correlation between profitability and the number of days accounts receivable, inventories and accounts payable (A/P). However, Deloof (2003) found that the coefficient of the cash conversion cycle variable is negative, but not at a significant level $(p$-value $=0.668)$.

Lazaridis and Tryfonidis (2006) studied the correlations between working capital and profitability with the 2001-2004 period data obtained from 131 companies in the Athens Stock Exchange. They found a statistically significant correlation between profitability and cash conversion cycle. Lazaridis and Tryfonidis (2006) reported that managers could increase profitability by keeping working capital components at an optimum level.

Ganesan (2007) studied the 2001-2007 period financial statements of 349 telecommunication equipment companies, and analysed the effects of working capital management. Ganesan (2007) found negative correlations between working capital management and profitability and liquidity. It was reported that average collection period had no significant effect on profitability and return of assets. According to Ganesan (2007), this was resulted from that the sector required fixed assets investment to a large extent. In addition, Ganesan (2007) did not find any significant statistical evidence that telecommunication equipment industry managed all of the components of working capital management equally.

Raheman and Nasr (2007) studied the correlations between working capital management and profitability with the 1999-2004 period data obtained from 94 Pakistani companies listed in Karachi Stock Exchange. They examined the effects of various components of working capital such as: average collection period, cash conversion cycle, and current ratio on the profitability of the companies. They found strong negative correlations between working capital components and profitability. According to Raheman and Nasr (2007), increase in cash conversion cycle results in a decrease in company profitability, and managers can create positive value growth by keeping cash conversion cycle at the possible lowest level. They also found negative correlations between profitability and current ratio and debt ratio. Additionally, they found a positive correlation between profitability and sales. 
Nazir and Afza (2009) studied the 1998-2005 period data of 204 publicly-traded companies in Karachi Stock Exchange. They examined the effects of aggressive working capital management policies on profitability of companies. According to the findings of the research, there are negative correlations between company profitability, working capital investments, and aggression of the financing policies of the companies. These findings of this research were not in agreement with previous researches. According to the authors, this was because of the volatile economic conditions of Pakistan.

Mathuva (2010) analysed the 1993-2008 period data of 30 publicly-traded companies in Nairobi Stock Exchange, and examined the effects of working capital components on profitability. According to the findings, there is a strong negative correlation between profitability and debt collection period. Mathuva (2010) also found a strong positive correlation between inventory conversion period and profitability. In addition, there was a positive correlation between average payment period and profitability.

Gill et al. (2010) analysed the 2005-2007 data of 88 American listed companies in New York Stock Exchange, and studied the correlation between profitability and working capital management. The findings showed that slow collection of A/R decreased corporate profitability. Gill et al. (2010) reported that managers could increase profitability by shortening the term to maturity. However, they did not state how the companies could do this and how they could compete with other companies in the sector. Gill et al. (2010) could not find any significant correlations between average collection period and number of days in inventory. Unlike other researches in the literature, they found a positive correlation between cash conversion cycle and profitability.

Mohamad and Saad (2010) studied the effects of working capital management from profitability and market valuation perspectives on the performance of Malaysian listed companies. They analysed the 2003-2007 period data obtained from randomly selected 172 publicly-traded companies. Mohamad and Saad (2010) studied Tobin $Q$, return on assets, and return on investment capital as dependent variables for three different hypotheses; and examined the correlations between these variables and working capital components. According to their findings, there are negative correlations between working capital components and all three dependent variables. However, $R$ square and adjusted $R$ square values of the models used in the research presented weak statistical correlations for all three models.

Ching et al. (2011) analysed the 2005-2009 period data of two different groups including 16 companies each, in order to examine the correlation between profitability and working capital among publicly-traded companies. Working capital had an important place for the total assets of the first group companies. On the other hand, fixed assets had an important share in the total assets of the second group companies. Ching et al. (2011) also tried to determine the working capital assets that affected profitability most. They used three different indicators of profitability: return on sales, return on assets, and return on equity. Cash conversion efficiency, debt ratio, days of working capital, days receivable, and days inventory were the independent variables of the research. According to their findings, working capital management was of equal importance in determining the profitability for both groups. Return on assets and return on sales were statistically significant for both groups. However, return on equity was statistically insignificant for both groups. Cash conversion efficiency and days inventory were the independent variables that affected the return on sales most for the first group companies for which working capital had an important place in their total assets. "Days in inventory" was the independent variable, which affected return on assets most for the companies in this group. Days of working capital and debt ratio were the working capital components that affected the profitability most for the second group companies for which fixed assets had an important place in the total assets. 


\section{Research Methodology}

\section{Measurement}

Measures for working capital management and profitability were taken from Deloof (2003) so that we could compare with previous researches in the literature. Lazaridis and Tryfonidis (2006), Ganesan (2007), and Gill et al. (2010) also used the same measures in their researches. The variables and their calculations are as follows.

Profitability was the dependent variable for all models of the research. Gross profit was calculated by subtracting cost of goods sold. Then, the obtained value was divided by the number obtained by subtracting financial asset amount from total assets. Deloof (2003) claimed that return on assets could not be a measure of profitability for companies that have financial assets to a great extent in their balance, because the profit from the main activities had a small share in the total profit of such companies:

$$
\text { Growth Profit }=(\text { Sales }- \text { Cost of Goods Sold }) /(\text { Total Asset }- \text { Financial Assets })
$$

Number of days inventory was calculated by dividing average inventories by the firm's average daily cost of goods sold. Inventory was divided by the cost of sold goods instead of sales price, because inventories are moved to costs when they are sold. Therefore, cost amount should be compared with another cost amount (Leach \& Melicher, 2011):

$$
\text { Number of Days Inventory }=(\text { Inventory / Cost of Goods Sold }) * 365
$$

Number of days account receivables (A/R) refers to the number of days a company takes to collect an account receivable. Number of days account receivables is calculated by dividing the average receivables by the net sales for a day. Receivables are proportioned by sales because credits opened to customers are related to sales amount:

$$
\text { Number of Days } A / R=(\text { Accounts Receivables / Sales }) * 365
$$

Number of days accounts payable (A/P) refers to the average credit time provided by the suppliers to the companies for raw material purchase:

$$
\text { Number of Days A/ P = (Accounts Payables / Cost of Goods Sold }) * 365
$$

The cash conversion cycle is the length of the time the firm has cash tied up in current assets. It is the number of days between receiving cash from the sale of its products and cash on productive resources. Computing a firm's cash conversion cycle entails summing number of days A/R and number of days inventory and subtracting its number of days A/P (Baker \& Powell, 2009):

$$
\begin{gathered}
\text { Cash Conversion Cycle }=(\text { Number of Days Account Receivables }+ \text { Number of } \\
\text { Days Inventory })- \text { Number of Days Accounts Payable }
\end{gathered}
$$

Firm size, financial debt ratio, and fixed financial asset ratio were used as control variables in the present research and were calculated as follows:

Firm Size = Natural Logarithm of Sales;

Financial Debt Ratio = $($ Short-Term Loans + Long-Term Loans $) /$ Total Assets;

Fixed Financial Asset Ratio = Fixed Financial Assets/Total Assets. 


\section{Data Collection}

The present research studied the manufacturing industry companies, which are listed in Borsa Istanbul Stock Exchange (BIST). The 2002-2013 period financial statement data of 171 publicly-traded companies in BIST Industrials were obtained from Bloomberg Finance L.P.. Some of the companies started to be traded after 2002, and the financial statement data of some companies were lost. For these reasons, the ultimate sample was formed with 106 companies. The present research consists of 1,248 observations related to 2002-2013 data of 106 companies.

\section{Descriptive Statistics}

Table 1 presents the descriptive statistics related to the variables used in the present research. A total number of 1,248 observations were conducted within the present research. Gross profit forms the $21.88 \%$ of the total assets (except financial assets). The companies in the present research collect their receivables in an average of 75.06 days, while they pay their debts to their suppliers in an average of 57.85 days. Inventories can only be sold in an average of 86.79 days after they arrive in the enterprises. These data show that the companies in the sample have an average cash conversion cycle of 104.01 days.

Table 1

Descriptive Statistics of Independent, Dependent, and Control Variables

\begin{tabular}{llccc}
\hline Variable & $N$ & Mean & Median & Std. deviation \\
\hline Gross profit & 1,248 & 0.2188 & 0.2000 & 0.13125 \\
Fixed financial asset & 1,248 & 0.0448 & 0.0100 & 0.08604 \\
Financial debt ratio & 1,248 & 0.1939 & 0.1600 & 0.17623 \\
Cash conversion cycle & 1,248 & 104.010 & 96.6950 & 79.22076 \\
LN sales & 1,248 & 19.3108 & 19.1100 & 1.50717 \\
No. of days A/R & 1,248 & 75.0648 & 67.1800 & 51.25810 \\
No. of days inventory & 1,248 & 86.7934 & 77.0750 & 57.39639 \\
No. of days A/P & 1,248 & 57.8492 & 47.8100 & 39.53588 \\
\hline
\end{tabular}

Table 2

Pearson Correlation Coefficients

\begin{tabular}{|c|c|c|c|c|c|c|c|c|}
\hline Variable & & Gross profit & Fixed FA & $\begin{array}{l}\text { Financial } \\
\text { debt }\end{array}$ & $\begin{array}{l}\text { Cash } \\
\text { conversion } \\
\text { cycle }\end{array}$ & LN sales & $\mathrm{A} / \mathrm{R}$ & $\begin{array}{l}\text { No. of days } \\
\text { inventory }\end{array}$ \\
\hline \multirow{2}{*}{ Fixed FA } & $\mathrm{r}$ & 0.100 & & & & & & \\
\hline & $\mathrm{P}$ & 0.000 & & & & & & \\
\hline \multirow{2}{*}{ Financial debt } & $\mathrm{r}$ & -0.084 & -0.025 & & & & & \\
\hline & $\mathrm{P}$ & 0.003 & 0.386 & & & & & \\
\hline \multirow{2}{*}{$\begin{array}{l}\text { Cash conversion } \\
\text { cycle }\end{array}$} & $\mathrm{r}$ & -0.023 & -0.086 & 0.058 & & & & \\
\hline & $\mathrm{P}$ & 0.421 & 0.002 & 0.041 & & & & \\
\hline \multirow{2}{*}{ LN sales } & $\mathrm{r}$ & -0.013 & -0.045 & 0.113 & -0.350 & & & \\
\hline & $\mathrm{P}$ & 0.651 & 0.114 & 0.000 & 0.000 & & & \\
\hline \multirow{2}{*}{$\mathrm{A} / \mathrm{R}$} & $\mathrm{r}$ & -0.094 & -0.041 & 0.083 & 0.626 & -0.235 & & \\
\hline & $\mathrm{P}$ & 0.001 & 0.148 & 0.003 & 0.000 & 0.000 & & \\
\hline \multirow{2}{*}{ No. of days inventory } & $\mathrm{r}$ & 0.045 & -0.111 & 0.047 & 0.698 & -0.334 & 0.137 & \\
\hline & $\mathrm{P}$ & 0.115 & 0.000 & 0.099 & 0.000 & 0.000 & 0.000 & \\
\hline \multirow{2}{*}{$\mathrm{A} / \mathrm{P}$} & $\mathrm{r}$ & -0.012 & -0.042 & 0.060 & -0.178 & -0.087 & 0.240 & 0.229 \\
\hline & $\mathrm{P}$ & 0.678 & 0.141 & 0.033 & 0.000 & 0.002 & 0.000 & 0.000 \\
\hline
\end{tabular}


Table 2 presents the Pearson correlation table for the variables that were included in our regression model. We observed that the gross profit was significantly negatively correlated with the variables financial debt ratio and number of days inventory. Additionally, there is a significant positive correlation between the gross profit and fixed financial asset ratio. On the other hand, fixed financial asset ratio is significantly negatively correlated with the variables cash conversion cycle and number of days inventory. Financial debt ratio is significantly positively correlated with variables cash conversion cycle, LN sales, number of days A/R, and number of days A/P. Cash conversion cycle is significantly negatively correlated with the variables LN sales and number of days $\mathrm{A} / \mathrm{P}$. Also, cash conversion cycle is significantly positively correlated with the variables number of days $A / R$ and number of days inventory. LN sales is significantly negatively correlated with the variables number of days $\mathrm{A} / \mathrm{R}$, number of days inventory, and number of days $\mathrm{A} / \mathrm{P}$. Also, number of days $\mathrm{A} / \mathrm{R}$ is significantly negatively correlated with the variables number of days inventory and number of days A/P. Moreover, there is a positive correlation between number of days A/P and number of days inventory.

\section{Regression Analysis}

The independent variables are fixed financial asset, financial debt ratio, cash conversion cycle, and LN sales. The total number of observations is 1,248, which represents stacked data for the period of 2002-2013 for listed firms in Turkey. Following is the first regression, where gross profit is regressed against fixed financial assets, financial debt, LN sales, and cash conversion cycle variables.

The regression equation is:

$$
\text { Gross Profit }=0.231+0.148 \text { Fixed FA }-0.060 \text { Financial }-0.00001800 \text { Cash }+0.000 \text { LN Sales }
$$

Table 3

The Relationship Between Profitability and Cash Conversion Cycle

\begin{tabular}{llllll}
\hline Predictor & Coef. & SE coef. & $T$ & $P$ & VIF \\
\hline Constant & 0.231 & 0.053 & 4.342 & 0.000 & \\
Fixed FA & 0.148 & 0.043 & 3.423 & 0.001 & 1.0 \\
Financial debt ratio & -0.060 & 0.021 & -2.838 & 0.005 & 1.0 \\
Cash conversion cycle & -0.00001800 & 0.000 & -0.358 & 0.721 & 1.2 \\
LN sales & 0.000 & 0.003 & -0.104 & 0.918 & 1.2 \\
S $=0.130$ & & & & & \\
$R$-sq. $=1.7 \%$ & & & & & \\
$R$-sq. (Adj.) $=1.4 \%$ & & & & & \\
\hline
\end{tabular}

Table 4

Analysis of Variance

\begin{tabular}{lrrlll}
\hline Source & DF & SS & MS & $F$ & $P$ \\
\hline Regression & 4 & 0.361 & 0.090 & 5.304 & 0.000 \\
Source error & 1,243 & 21.122 & 0.017 & & \\
Total & 1,247 & 21.483 & & & \\
Durbin-Watson statistic $=0.657$ & & & & & \\
\hline
\end{tabular}

This regression equation shows that there is a negative relationship between cash conversion cycle and profitability (see Table 3), which is consistent with the view that a decrease in the cash conversion cycle will generate more profits for a company. The above result is insignificant. Meanwhile, the rest of the model variables are statistically significant where gross profit increases as fixed financial asset ratio increases, while 
financial debt ratio has a negative coefficient. The F-test equals to 5.304 and is highly significant (see Table 4). This result makes economic sense since if all coefficients were zero, then a firm would have positive results, i.e., gross profit $=0.231$.

The regression equation is:

$$
\begin{gathered}
\text { Gross Profit }=0.276+0.143 \text { Fixed FA-0.054 Financial }-0.000 \text { No. of Days A } R \\
-0.002 \text { LN Sales }
\end{gathered}
$$

Table 5

The Relationship Between Profitability and Accounts Receivables

\begin{tabular}{lcllll}
\hline Predictor & Coef. & SE coef. & $T$ & $P$ & VIF \\
\hline Constant & 0.276 & 0.051 & 5.463 & 0.000 & \\
Fixed FA & 0.143 & 0.043 & 3.333 & 0.001 & 1.0 \\
Financial debt ratio & -0.054 & 0.021 & -2.535 & 0.011 & 1.0 \\
No. of days A/R & -0.000 & 0.000 & -3.079 & 0.002 & 1.1 \\
LN sales & -0.002 & 0.003 & -0.738 & 0.461 & 1.1 \\
S = 0.155 & & & & & \\
$R$-sq. = 2.4\% & & & & & \\
$R$-sq. (Adj.)=2.1\% & & & & & \\
\hline
\end{tabular}

Table 6

Analysis of Variance

\begin{tabular}{lrrlll}
\hline Source & DF & SS & MS & $F$ & $P$ \\
\hline Regression & 4 & 0.518 & 0.130 & 7.681 & 0.000 \\
Source error & 1,243 & 20.964 & 0.017 & & \\
Total & 1,247 & 21.483 & & & \\
Durbin-Watson statistic $=0.646$ & & & & & \\
\hline
\end{tabular}

In the second regression, we have the dependent variable gross profit and the same independent variables as in the first regression equation. We observed that there is a negative relationship between gross operating profit and accounts receivables (see Tables 5 and 6).

In the third equation, the results show that there is a positive relationship between gross operating profit and number of days inventory (see Tables 7 and 8).

The regression equation is:

$$
\begin{gathered}
\text { Gross Profit }=0.169+0.163 \text { Fixed FA-0.065 Financial }+0.000 \text { No. of Days Inventory } \\
+0.002 \text { LN Sales }
\end{gathered}
$$

Table 7

The Relationship Between Profitability and Inventory

\begin{tabular}{lcllll}
\hline Predictor & Coef. & SE coef. & $T$ & $P$ & VIF \\
\hline Constant & 0.169 & 0.053 & 3.181 & 0.002 & \\
Fixed FA & 0.163 & 0.043 & 3.760 & 0.000 & 1.0 \\
Financial debt ratio & -0.065 & 0.021 & -3.086 & 0.002 & 1.0 \\
No. of days inventory & 0.000 & 0.000 & 2.282 & 0.023 & 1.2 \\
LN sales & 0.002 & 0.003 & 0.823 & 0.411 & 1.2 \\
S $=0.144$ & & & & & \\
$R$-sq. $=2.1 \%$ & & & & & \\
$R$-sq. (Adj.) $=1.8 \%$ & & & & & \\
\hline
\end{tabular}


Table 8

Analysis of Variance

\begin{tabular}{lrrlll}
\hline Source & DF & SS & MS & $F$ & $P$ \\
\hline Regression & 4 & 0.446 & 0.112 & 6.595 & 0.000 \\
Source error & 1,243 & 21.036 & 0.017 & & \\
Total & 1,247 & 21.483 & & & \\
Durbin-Watson statistic $=0.665$ & & & & & \\
\hline
\end{tabular}

In the last regression, we added number of days for $\mathrm{A} / \mathrm{P}$ in an attempt to explain gross operating profit. Although there is a negative relationship between gross profit and number of days for A/P, this result is not statistically significant (see Tables 9 and 10).

The regression equation is:

$$
\begin{gathered}
\text { Gross Profit }=0.223+0.149 \text { Fixed FA-0.061 Financial }-0.00009 \text { No. of Days A } / P \\
+0.00002 \text { LN Sales }
\end{gathered}
$$

Table 9

The Relationship Between Profitability and Accounts Payable

\begin{tabular}{llllll}
\hline Predictor & Coef. & SE coef. & $T$ & $P$ & VIF \\
\hline Constant & 0.223 & 0.049 & 4.594 & 0.000 & \\
Fixed FA & 0.149 & 0.043 & 3.474 & 0.001 & 1.0 \\
Financial debt ratio & -0.061 & 0.021 & -2.876 & 0.004 & 1.0 \\
No. of days A/P & -0.00009 & 0.000 & -0.096 & 0.923 & 1.0 \\
LN sales & 0.00002 & 0.002 & 0.019 & 0.984 & 1.0 \\
S = 0.129 & & & & & \\
$R$-sq. = 1.7\% & & & & & \\
$R$-sq. (Adj.) =1.4\% & & & & & \\
\hline
\end{tabular}

Table 10

Analysis of Variance

\begin{tabular}{lrrlll}
\hline Source & DF & SS & MS & $F$ & $P$ \\
\hline Regression & 4 & 0.359 & 0.090 & 6.274 & 0.000 \\
Source error & 1,243 & 21.124 & 0.017 & & \\
Total & 1,247 & 21.483 & & & \\
Durbin-Watson statistic $=0.657$ & & & & & \\
\hline
\end{tabular}

All regression models were tested for multicollinearity. The VIF was used to detect whether one predictor had a strong linear association with the other predictors (the presence of multicollinearity among the predictors). VIF measures how much the variance of an estimated regression coefficient increases if your predictors are correlated (multicollinear). The largest VIF among all predictors is often used as an indicator of severe multicollinearity.

\section{Conclusion}

Analysis of working capital management effect on profitability was conducted on a sample of 106 industrial companies in BIST. We observed that the gross profit was significantly negatively correlated with the variables financial debt ratio and number of days inventory. In addition, there is a significant positive correlation between the gross profit and fixed financial asset ratio. On the other hand, fixed financial asset ratio 
is significantly negatively correlated with the variables cash conversion cycle and number of days inventory. First regression equation shows that there is a negative relationship between cash conversion cycle and profitability which is consistent with the view that a decrease in the cash conversion cycle will generate more profits for a company but the result is insignificant.

We observed that there was a negative relationship between gross operating profit and accounts receivables. Lazaridis and Tryfonidis (2006), Raheman and Nasr (2007), Deloof (2003), Gill et al. (2010), and Mathuva (2010) predicted a negative relationship between accounts receivables and corporate profitability. Our findings are in agreement with these findings. But accounts receivables do not have a significant effect on the profitability of firms in the present study. We also found that there was a positive relationship between gross operating profit and number of days inventory. The literature presents opposing results except Gill et al. (2010).

\section{References}

Baker, H. K., \& Powell, G. (2009). Understanding financial management: A practical guide. John Wiley \& Sons.

Ching, H. Y., Novazzi, A., \& Gerab, F. (2011). Relationship between working capital management and profitability in Brazilian listed companies. Journal of Global Business and Economics, 3(1), 74-86.

Deloof, M. (2003). Does working capital management affect profitability of Belgian firms? Journal of Business Finance \& Accounting, 30(3-4), 573-588.

Ganesan, V. (2007). An analysis of working capital management efficiency in telecommunication equipment industry. Rivier Academic Journal, 3(2), 1-10.

Gill, A., Biger, N., \& Mathur, N. (2010). The relationship between working capital management and profitability: Evidence from the United States. Business and Economics Journal, 10, 1-9.

Lazaridis, I., \& Tryfonidis, D. (2006). Relationship between working capital management and profitability of listed companies in the Athens Stock Exchange. Journal of Financial Management \& Analysis, 19(1), 26-35.

Leach, J. C., \& Melicher, R. W. (2011). Entrepreneurial finance. Cengage Learning.

Mathuva, D. M. (2010). The influence of working capital management components on corporate profitability: A survey on Kenyan listed firms. Research Journal of Business Management, 4(1), 1-11.

Mohamad, N. E. A. B., \& Saad, N. B. M. (2010). Working capital management: The effect of market valuation and profitability in Malaysia. International Journal of Business and Management, 5(11), 140-147.

Nazir, M. S., \& Afza, T. (2009). Impact of aggressive working capital management policy on firms' profitability. The IUP Journal of Applied Finance, 15(8), 19-30.

Raheman, A., \& Nasr, M. (2007). Working capital management and profitability - Case of Pakistani firms. International Review of Business Research Papers, 3(1), 279-300.

Shin, H. H., \& Soenen, L. (1998). Efficiency of working capital management and corporate profitability. Financial Practice \& Education, 8(2), 37-45. 